\title{
THE SHOW CAVE AT "GRAN CAVERNA DE SANTO TOMÁS" (PINAR DEL RIO PROVINCE, CUBA)
}

\author{
TURISTIČNA JAMA "GRAN CAVERNA DE SANTO TOMÁS" \\ (PROVINCA PINAR DEL RIO, KUBA)
}

MARIO PARISE ${ }^{1,2} \&$ MANUEL VALDES SUAREZ ${ }^{2,3}$

\footnotetext{
${ }^{1}$ National Research Council, IRPI, Bari, Italy

${ }^{2}$ Gruppo Puglia Grotte, Castellana-Grotte (BA), Italy

${ }^{3}$ Sociedad Espeleologica de Cuba
}

Prejeto / received: 2. 3. 2005 


\begin{abstract}
UDC $551.44: 338.48(729.1)$

Mario Parise \& Manuel Valdes Suarez: The show cave at "Gran Caverna de Santo Tomás" (Pinar del Rio province, Cuba)
\end{abstract}

At Gran Caverna de Santo Tomàs, one of the longest karst system of Cuba, a part of the cave is exploited since 1994 as show cave. It corresponds to the sixth level (out of the total of seven) of the complex karst system, which lowest part is still active today, being the present course of Arroyo Santo Tomàs. Even with the difficulties related to great distance from the main tourist routes of the island, Gran Caverna de Santo Tomàs was visited in the last 10 years by a significant number of tourists and scientists, due to its remarkable variety of karst landscape, at the surface as well as within the cave, and the important archaeological discoveries therein carried out. Management of the show cave is a good example of low-impact effect of tourism in a karst cave, as many features point out. Among these, the limited number of visitors allowed for each group, the choice in using only wooden ladders and passages to reach the cave entrance, and the adoption of rechargeable electrical light (without realizing any fixed light system in the cave). Gran Caverna de Santo Tomàs, therefore, has a high potentiality for becoming one of the best location in the Caribbean to develop an ecological sustainable tourism and, at the same time, due to its size and length, to allow international and Cuban cavers and scientists to continue carrying out speleological and karst research.

Key words: karst, show cave, tourism, Cuba.

Izvleček

UDK $551.44: 338.48(729.1)$

Mario Parise \& Manuel Valdes Suarez: Turistična jama "Gran Caverna de Santo Tomás" (provinca Pinar del Rio, Kuba)

Del jame Gran Caverna de Santo Tomàs, ki eden najdaljših jamskih sistemov na Kubi, je urejen za turizem že od 1994. To je šesti nivo (od sedmih) tega kompleksnega kraškega sistema, katerega najnižji del je aktiven in teče skozenj potok Arroyo Santo Tomàs. Zaradi velike pestrosti kraških oblik, tako na površju kot v jami in zaradi pomembnih arheoloških odkritij, je jamo Gran Caverna de Santo Tomàs v zadnjih 10 letih obiskalo pomembno število turistov in znanstvenikov, kljub težavam zaradi oddaljenosti od glavnih turističnih poti po otoku. Več elementov potrjuje, da je upravljanje z jamo lep primer majhnega vpliva turizma na jamo. Med temi je omejeno število obiskovalcev v skupini, uporaba zgolj lesa za lestve in mostičke za dostop do jamskega vhoda ter uporaba akumulatorskih električnih svetilk (ne da bi bil v jami nameščen stalni sistem osvetljevanja). Zato ima Gran Caverna de Santo Tomàs velike možnosti da postane eno najpomembnejših mest na Karibih, kjer bi lahko na eni strani razvijali ekološki in trajnostni turizem, na drugi pa bi, zaradi svoje velikosti in dolžine, vabila mednarodne in kubanske jamarje ter znanstvenike k stalnim speleološkim in krasoslovnim raziskavam.

Ključne besede: kras, turistična jama, turizem, Kuba. 


\section{INTRODUCTION}

Ninety percent of the Caribbean's $130,000 \mathrm{~km}^{2}$ of karst is in the Greater Antilles, particularly Cuba, Hispaniola, Jamaica and Puerto Rico, with smaller areas in the Bahamas, the Lesser Antilles, Trinidad and the Netherlands Antilles (Monroe 1968; Day 1978; Gardner 1987; Day \& Koenig 2002; Tarhule-Lips 2003). About 70\% of Cuba has carbonate rocks at outcrop or beneath thin soil cover (Fig. 1), which makes this island one of the most interesting sites in the Caribbean as regards presence and variety of karst features.

Many Cuban caves are regarded as culturally and historically significant, particularly as a consequence of their military role during the 1959 socialist revolution. President Fidel Castro himself has considerable personal experience of caves and during the revolution he gained an appreciation " ... for this fragile environment, emphasizing the protection and conservation of caves" (Schenck et al. 1999, 300).

Speleological activities, caving, researches and explorations are therefore considered of great importance in Cuba, and particularly in the Pinar del Rio province, where the Gran Caverna de Santo Tomàs is located, as the foundation of the Escuela Nacional de Espeleologia in 1984, dedicated to Antonio Nuñez Jimenez and sited nearby some of the main cave entrances of the karst system, shows.

Several karst caves at Cuba have been developed as tourist sites. Among these, Cueva Grande de Santa Catalina and Cueva de Bellamar, both located in raised terraces in the Matanza province, are famous for their speleothems, including very large calcite crystals and large cones and mushrooms of fallen cave rafts (Tyc 2004). Cueva de Bellamar has, in addition, historical importance as show cave since, after its discovery in 1861 , it was soon shown to visitors for $1 \$$ "including guides and lights" (Shaw 2003).

This paper illustrates the management of the part of Santo Tomàs karst system which is exploited as show cave, and eventually presents some considerations about development of ecotourism in Cuba, and the possible monitoring of the cave, aimed at preservation of its natural environment.

\section{GEOLOGICAL AND MORPHOLOGICAL SETTING}

Gran Caverna de Santo Tomàs is located in western Cuba, and is among the most remarkable and well-known example of karst caves in the Caribbean. It is included in that part of the country where the cone karst is particularly well developed, with its best manifestation in the Sierra de los Organos. This is part of the mountain ridges of western Cuba, and is bounded by Sierra del Rosario to the east (Fig. 1), and by the plain of Pinar del Rio to the south and the southwest, the latter being an example of covered karst, under great thickness of alluvial deposits. The most peculiar features of the karst cone at Sierra de los Organos are the mogotes, residual karst hills which generally dominate, both as continuous ridges or as isolated hill, flat plains and valleys. The common profile for mogotes is conical, but locally they might have a tower profile; however, their height/width ratios are definitely lower than for towers of the Chinese karst (Tyc 2003).

Mogotes and the other ridges are separated by intervening flat areas, many of which are karsterosion poljes, formed at the contact between carbonate rocks and terrigenous, not soluble, deposits. This is the case for Valle de Viñales (Fig. 2), probably the best example with the many mogotes and the intensive tobacco fields which made possible its inclusion in 1999 in the World Heritage List. 


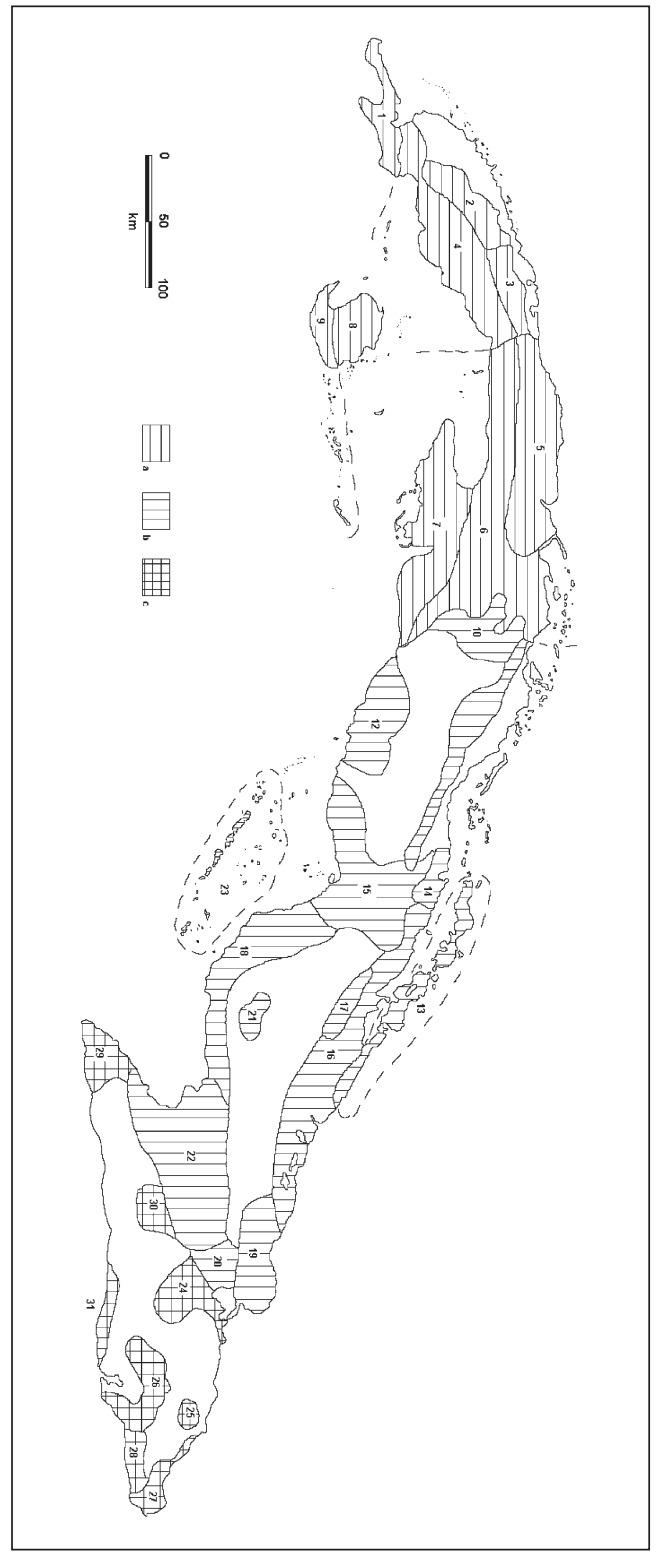

Fig. 1: Karst regions of Cuba (after Nuñez Jimenez, 1984, simplified). Explanation: a) west karst regions; b) central karst regions; c) eastern karst regions. The single karst region are listed in Table 1. No. 2 and no. 3 refers, respectively, to Sierra de los Organos and to Sierra del Rosario.
The southeastern part of the Sierra de los Organos is in the catchment basin of the Cuyaguateje River, where mogotes, poljes and karst valleys are particularly widespread. In this area the 8,5 km-long, NNW-SSE elongated ridge of Sierra de Quemado is located, which hosts the karst system of Gran Caverna de Santo Tomás. There, Sierra de los Organos leaves the typical E-W elongation of most of the Cuban mountain ridges to accommodate in a N-S direction, in the forms of a wide arch.

Sierra de Quemado is bounded to the west by the omonimous valley, whilst to the east there is the Valle de Santo Tomás. On the eastern side of the mountain, the Arroyo de Santo Tomás sinks into the Sierra, to come out to the west, after a course of a few kilometres. Once in the Valle de Quemado, the Arroyo de Santo Tomás joins the Rio Caoba, which, in turn, reaches to the south the Cuyaguateje River to flow through the Valle de Luiz Lazo toward the southern coast of Cuba.

\section{GRAN CAVERNA DE SANTO TOMÁS}

The Gran Caverna de Santo Tomás consists of seven main levels of mostly subhorizontal caves which develop at different altitudes in the Sierra de Quemado (Fig. 3). The lowest level (altitude $125 \mathrm{~m}$ a.s.l.) corresponds to the present underground course of Arroyo Santo Tomás, whilst the highest is at altitude of $190 \mathrm{~m}$ a.s.l., thus determining an overall relief of 65 meters.

This complex karst system (among the longest at Cuba, with its $46 \mathrm{~km}$ of explored caves) was recognized as National Monument on June 5, 1989, due to its naturalistic, karst, paleontological, archaeological and historical importance. In fact, Gran Caverna de Santo Tomás has offered remarkable 
prehistoric discoveries, including the engravings in the Cueva de Mesa (Nuñez Jimenez 1955), and a human skeleton in the Cueva Incognita. Dating of this latter provided an age of about 3500 years, based upon studies by the cuban archaeologist Rivero de la Calle.

Gran Caverna de Santo Tomás has, on the other hand, always had an important role for the local inhabitants: many of its caverns and galleries have provided shelter to cimarrones, the name which indicated the slaves escaped from the farms where they were forced to work during the first half of the XIX century. Farmers from Valle de Santo Tomás and Valle de Quemado have often used the water courses in the lowest levels of the karst system as resource of drinkable water during droughts, the caverns as shelters during cyclones, and extracted the rich guano deposits to be used as fertilizer. Even public activities were carried out, as the use of Cueva del Salon for parties and dances demonstrates, due to the size of the cavern and its easy access from Valle de Quemado.

The systematic explorations at Gran Caverna de Santo Tomás started in 1954 thanks to Antonio Nuñez Jimenez, the well-known explorer and caver, considered the Father of the Cuban Speleology. In four main phases of explorations, the last of which is still going on, over $46 \mathrm{~km}$ have been explored, surveyed and mapped (Nuñez Jimenez 1990; Valdes Suarez 2005). The most recent activity at Gran Caverna de Santo Tomás was the expedition "Santo Tomás 2003", carried out in December 2003 by italian and cuban cavers (Parise 2004). The present article is part of the work performed during that expedition.

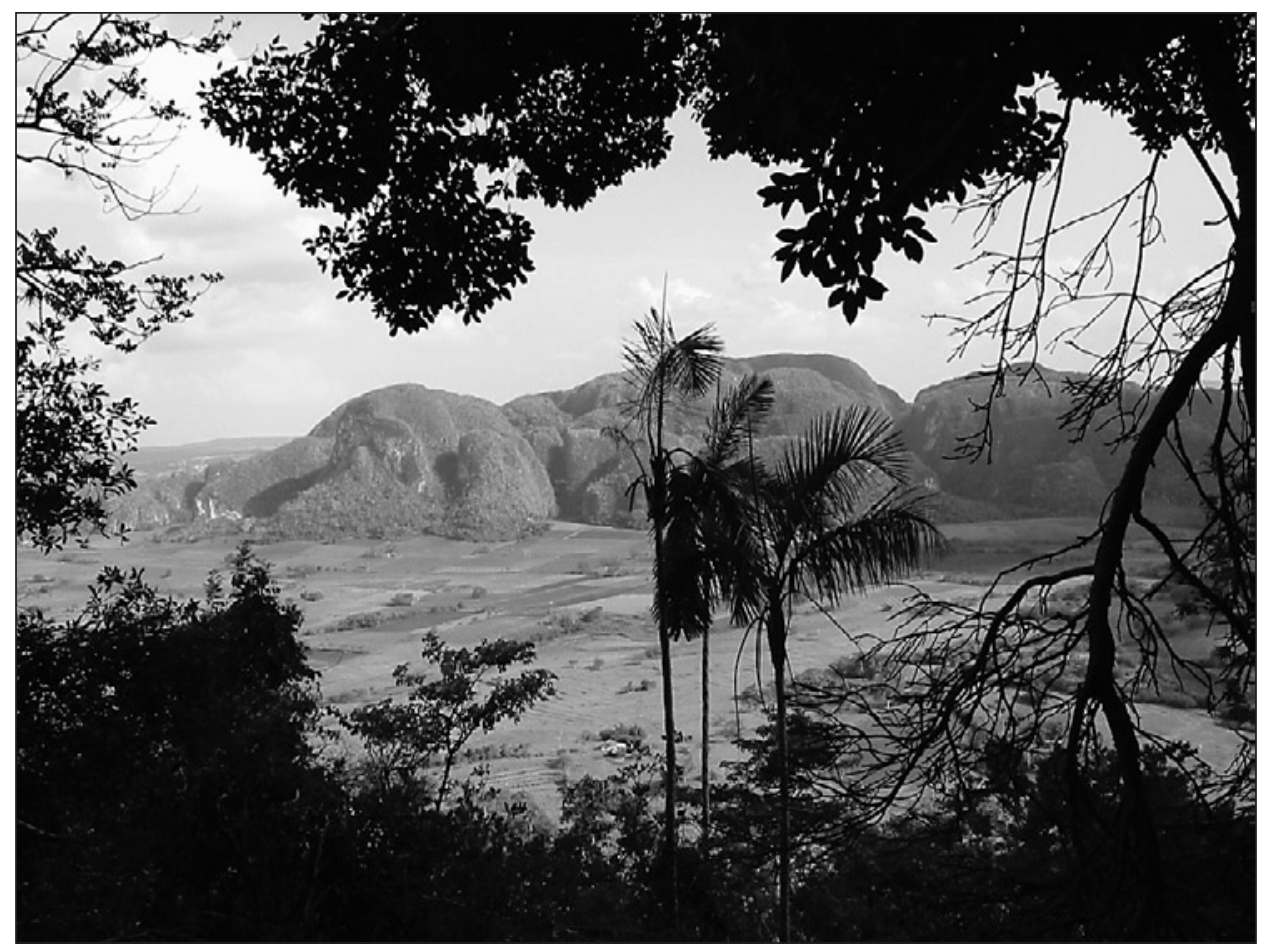

Fig. 2: View of the Valle de Viñales, one of the most typical feature of the cuban cone karst (photo courtesy Rosa Potenza). 


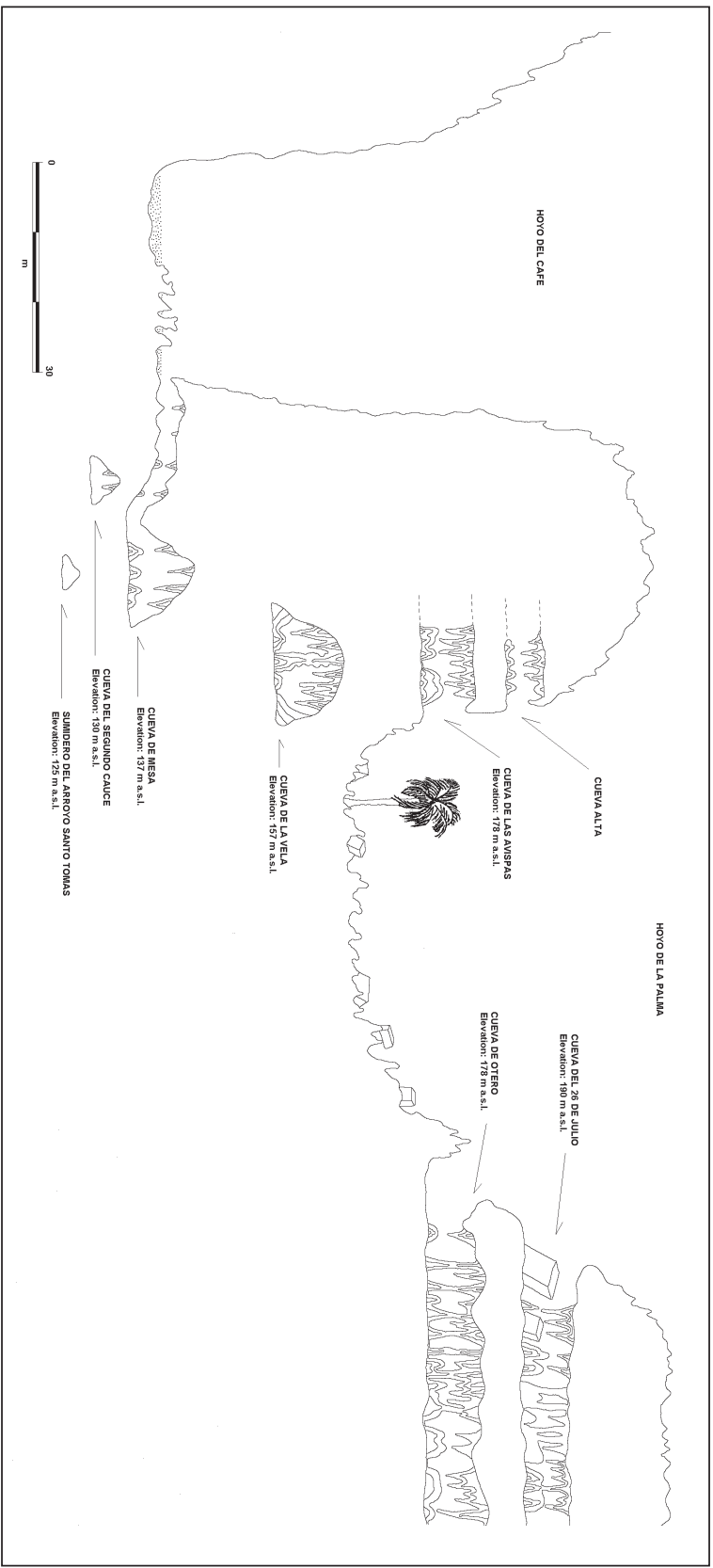

Fig. 3: Section through Sierra de Quemado, showing the seven levels of development of the karst system (after Nuñez. Jimenez, 1990, modified).

\section{THE SHOW CAVE AT SANTO TOMÀS}

The Escuela Nacional de Espeleologia "Antonio Nuñez Jimenez" is located at El Moncada village, just east of Sierra de Quemado. Few tens of meters from the school buildings, some of the entrances (Cueva Tapiada, Cueva Antorchas) to the Gran Caverna de Santo Tomás are located, at the lowest part of the mogote which rises above the school (Fig. 4).

The part of the Santo Tomàs karst system exploited as show cave since 1994 is the Cueva de las Avispas, so-called because of the swarm of bees which attacked the first explorers entering this part of the cave on August 9, 1956 (Nuñez Jimenez 1990). Cueva de las Avispas corresponds to the sixth level of the system (Figg. 3 and 5), at elevation of $178 \mathrm{~m}$ a.s.l. It is connected, at the same elevation, to Cueva de Otero, one among the several ways to reach the wide and magnificent Salòn del Caos (Fig. 6), probably the most remarkable cavern of Santo Tomàs, characterized by huge rockfall deposits (Nuñez Jimenez 1990; Parise 2004). The show cave is limited to Cueva de las Avispas, and the nearby Cueva de las Perlas, where it is possible to admire some of the most typical speleothems of the Santo Tomàs karst system.

Management of the show cave is guaranteed by the State society Ecovida, that manages also the Natural Park of Viñales, including the Gran Caverna de Santo Tomás. The fee for the visit is $8 \$$, a part of 
which is given to the Sociedad Espeleologica de Cuba, which has the task to train the local guides. The path within the karst system is about $350 \mathrm{~m}$ long, whilst the time duration of a visit is about 1 hour, including the time necessary to reach the cave by hiking along the path. In the case of show caves, one of the most important parameters is the visitor's capacity, that is the number of visitors allowed to enter the cave per day, per month, per year, without irreversible changes are produced in the cave environment (Kranjc 2002). The maximum number of visitors allowed for each visit is ten people, to ensure the control by the guide and reduce the tourist impact on the natural environment of the cave. In average, since opening to the public as a show cave, the Gran Caverna de Santo Tomás hosted about 1,500 visitors per year.

The visit starts from the speleological school, and proceeds through a nice path (Fig. 7) to reach the cave entrance. Along the path, the use of removable wooden ladders, foot-bridges and passages has to be properly highlighted. Too often, in fact, negative effects to the karst environment have been produced by wrong management actions within the cave, and at its outside as well: uncontrolled number of visitors, with large groups of people entering the cave; negative effects on the local fauna; importing huge amounts of concrete to build massive pathway systems; etc. (Cigna 2001; Travous \& Ream, 2001; Hamilton-Smith 2002; Mann et al. 2002). At Santo Tomàs, on the other hand, wooden stairs and passages are well integrated in the natural setting of the mogote vegetation; in addition, these structures may be easily removed at any time, without producing any negative effects on the

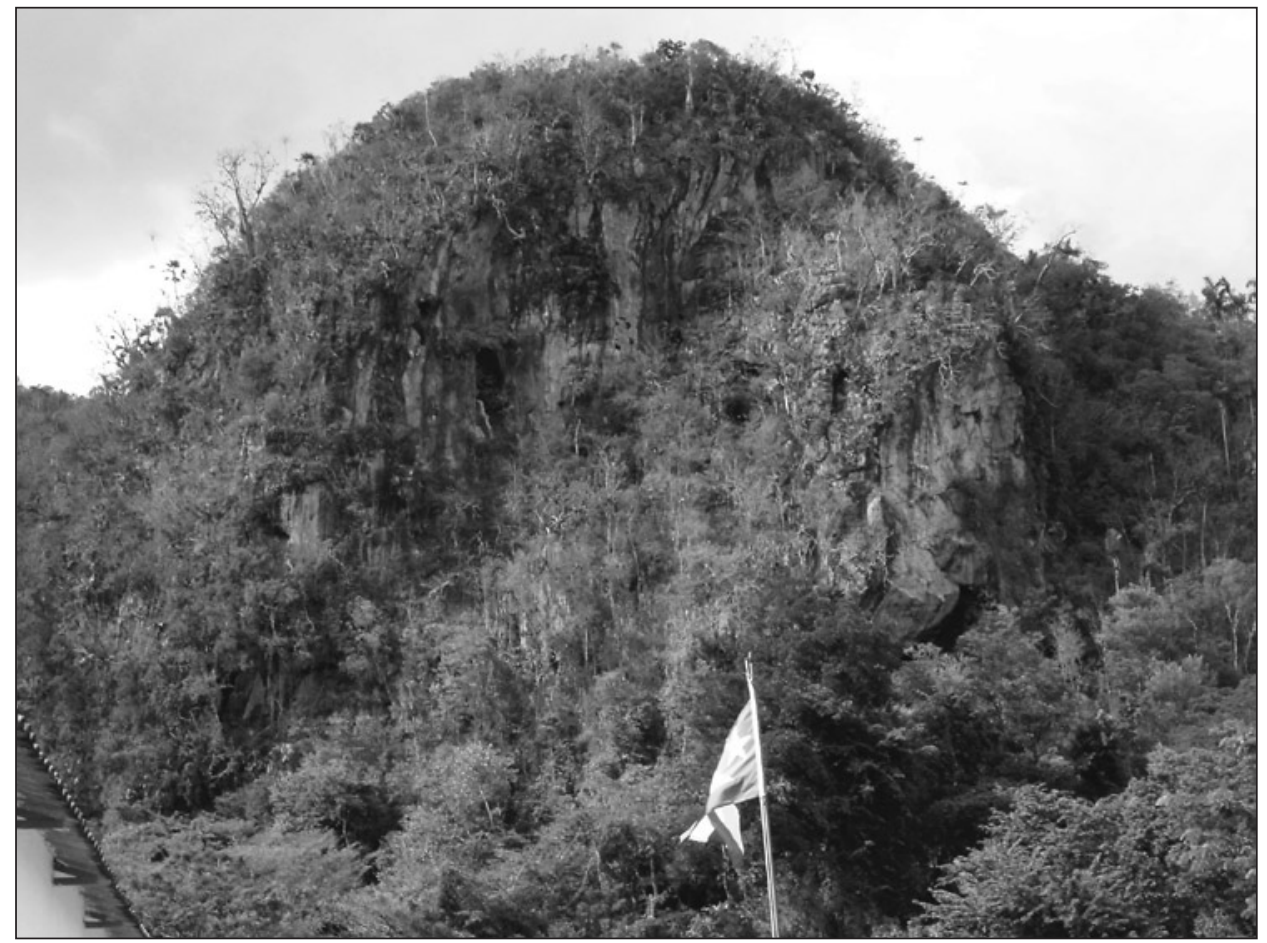

Fig. 4: The mogote just above the Escuela Nacional de Espeleologia “Antonio Nuñez. Jimenez" at El Moncada, a few tens of meters from some of the eastern entrances to the Santo Tomás karst system. 


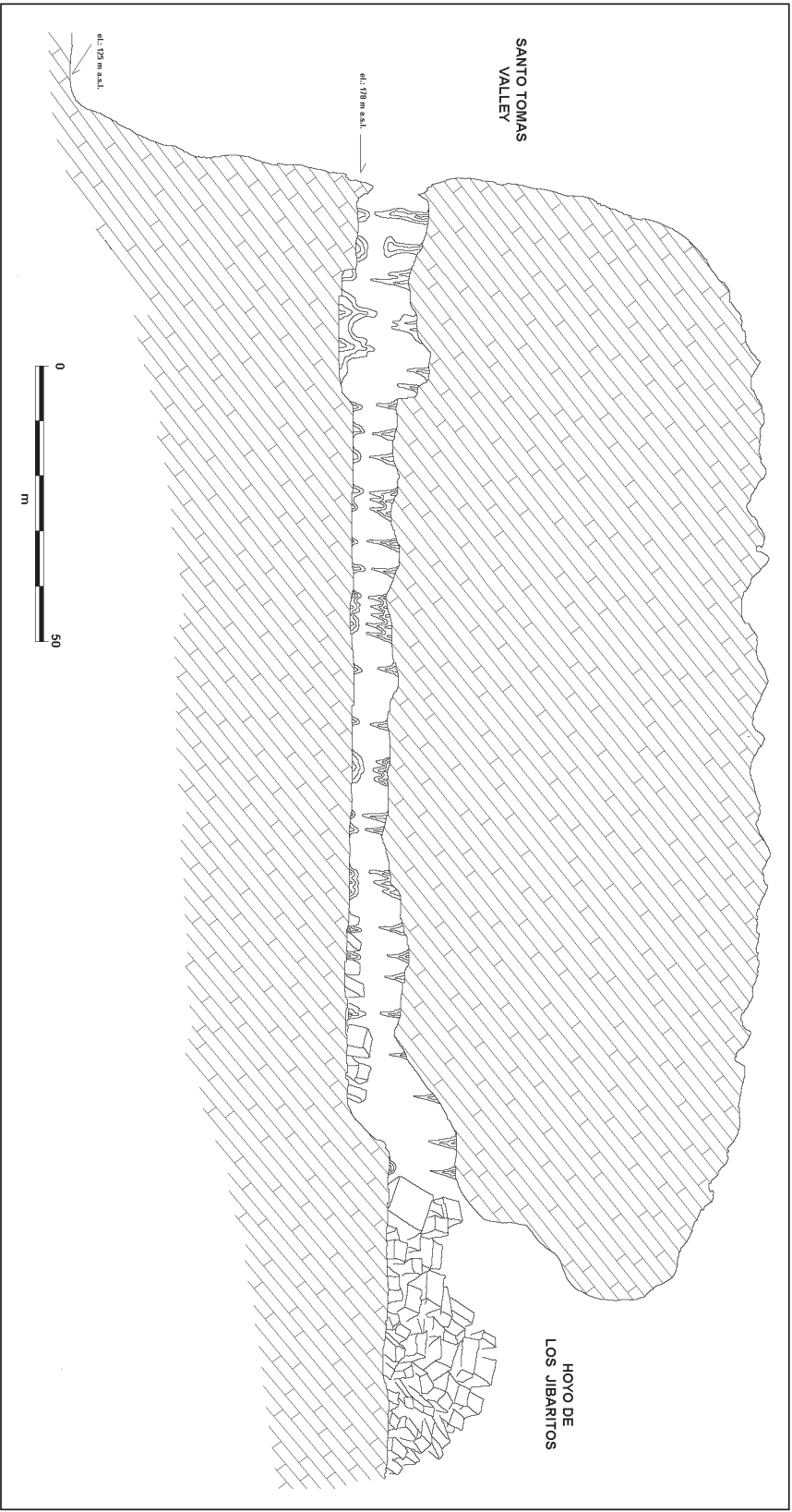

Fig. 5: Schematic section of Cueva de las Avispas, from its eastern entrance from the Valle de Santo Tomás to the Hoyo de los Jibaritos. At the lower left corner, at elevation of $125 \mathrm{~m}$ a.s.l., the Arroyo de Santo Tomás currently runs (after Nuñez Jimenez, 1990, modified). local karst landscape.

Once reached the cave access (Fig. 8), the visitors are introduced to some reconstructions illustrating the main discoveries performed at Santo Tomàs, from the engravings at Cueva de Mesa, to the archaeological findings at several locations of the karst system, to the beauty of the calcite concretions. These latter are particularly well exposed at Cueva de las Perlas, which is included in the visit. Even some stalactites, which inclination was tentatively explained by Nuñez Jimenez as due to air currents (similarly to those observed at Cueva de las Catacumbas, in another sector of the Santo Tomàs karst system), can be there observed (Fig. 9).

Throughout the visit, light is provided by electrical lamps mounted on the helmet worn for protection by each visitor. The lamp, with rechargeable battery, is another important aspect of the show cave management. It is well-known, in fact, that in show caves the increasing number of visitors, the artificial light systems, and other interventions made by man aimed at tourist utilization of the site produce changes of the physical and chemical conditions, including metereological and climatic changes which may irrevo- 


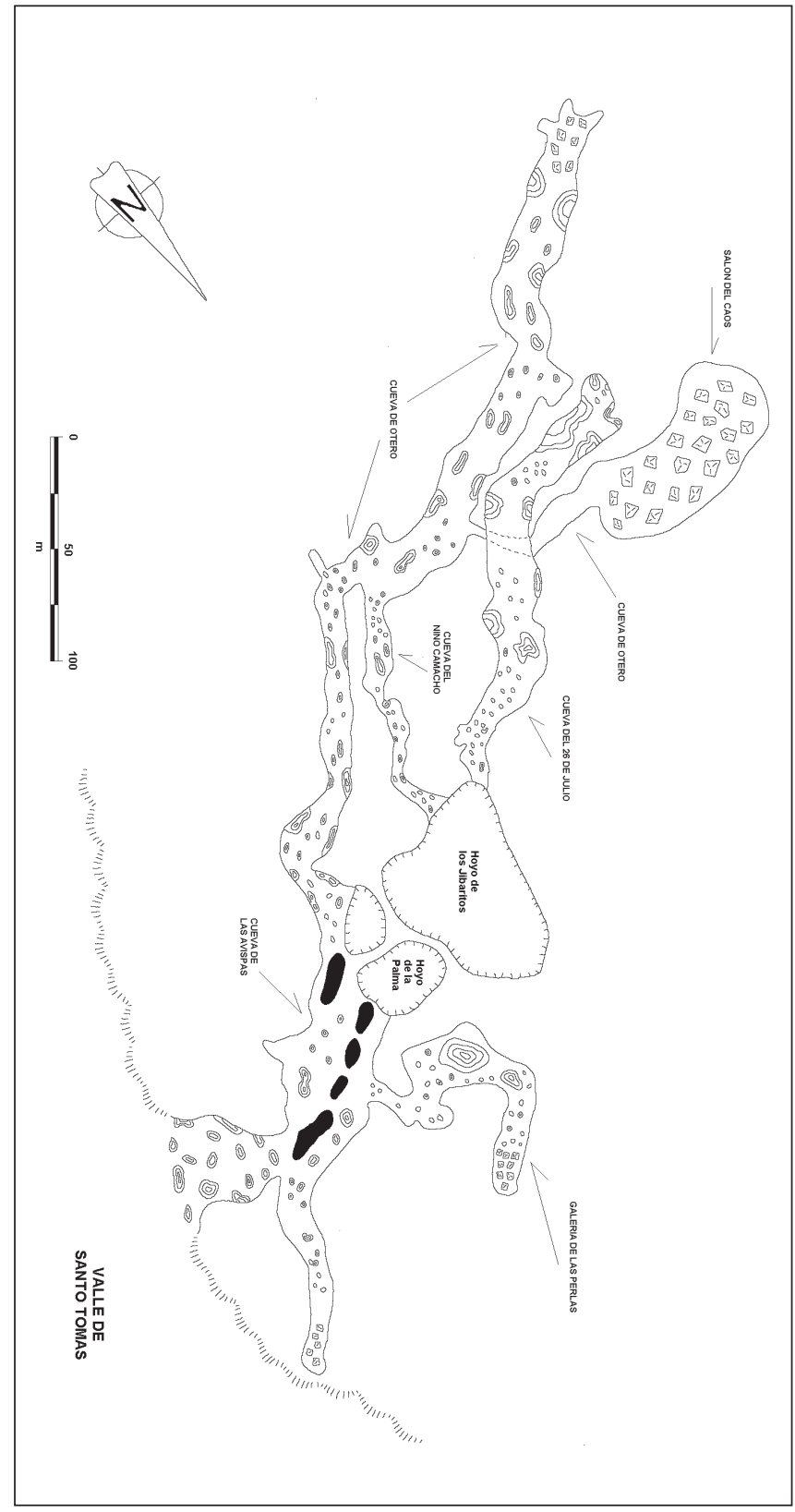

Fig. 6: Plan of a sector of the Santo Tomás karst system, from the access through Cueva de las Avispas to Salon del Caos. The part of the cave used as show cave develops from Cueva de las Avispas to Cueva de las Perlas (after Nuñez Jimenez, 1990, modified). cably affect the ecology and biology of the cave. Use of the electrical light at Santo Tomàs, on the other hand, avoided to perform any intervention in the cave to set fixed light system. Again, the option to protect the cave without interfering with it prevailed in the management choice. Some natural windows (Fig. 10) from the show cave allow the visitors to have a look at the valley below, where the village of El Moncada, and the Escuela Nacional de Espeleologia, from where they started the visit, are located.

Since the show cave is only limited to the outer part of the system, Cueva de las Avispas could well suit the requirement for becoming a site of research for the Santo Tomàs karst system. While continuing to offer the outer part of the cave as show cave, its prosecution could be monitored to various aims, starting from the control of likely changes in the cave related to the presence of tourists.

Similarly, other show caves have been partly used worldwide for research activities; one of the most interesting example is the Nerja Cave, located in Andalusia, south Spain. The cave, mostly horizontal, extends about $5 \mathrm{~km}$ in chambers and galleries with a difference 


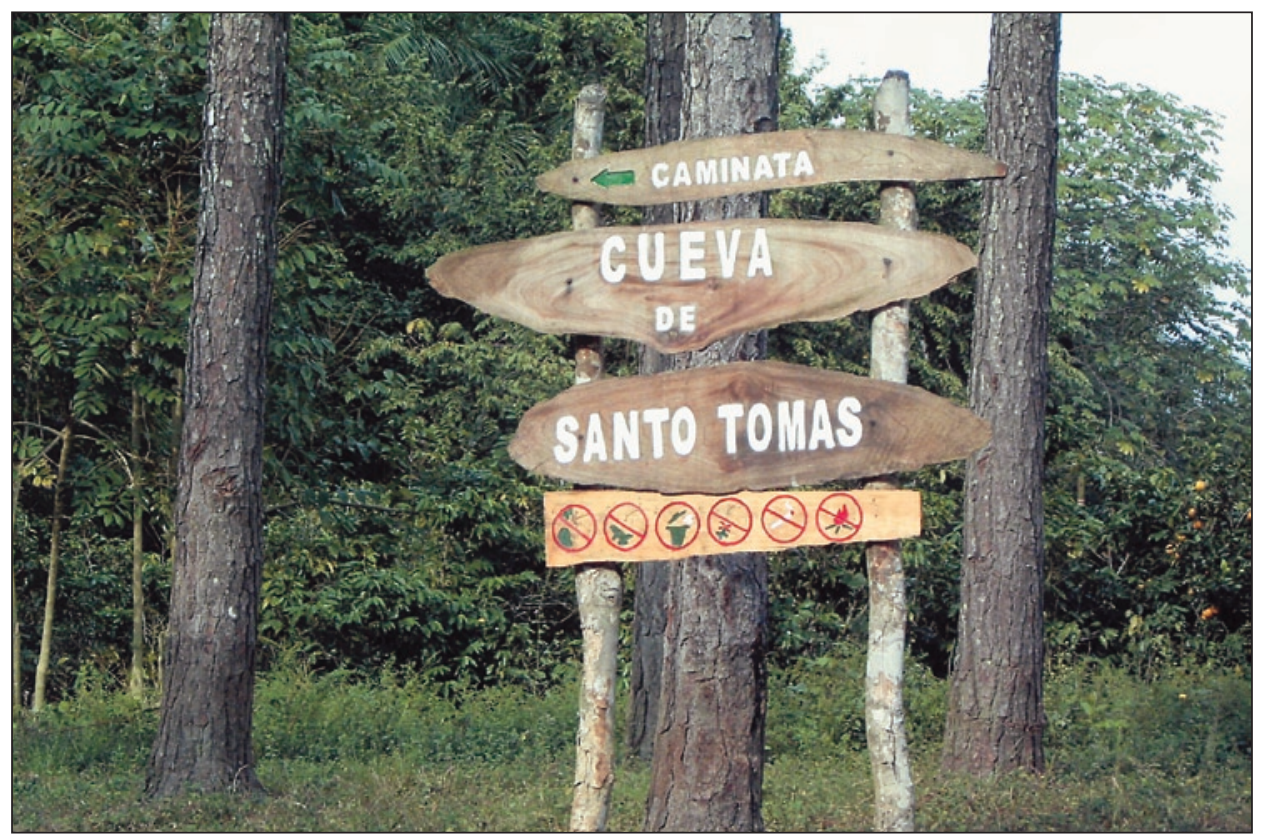

Fig. 7: Wooden signs indicating the route toward the tourist part of the cave.

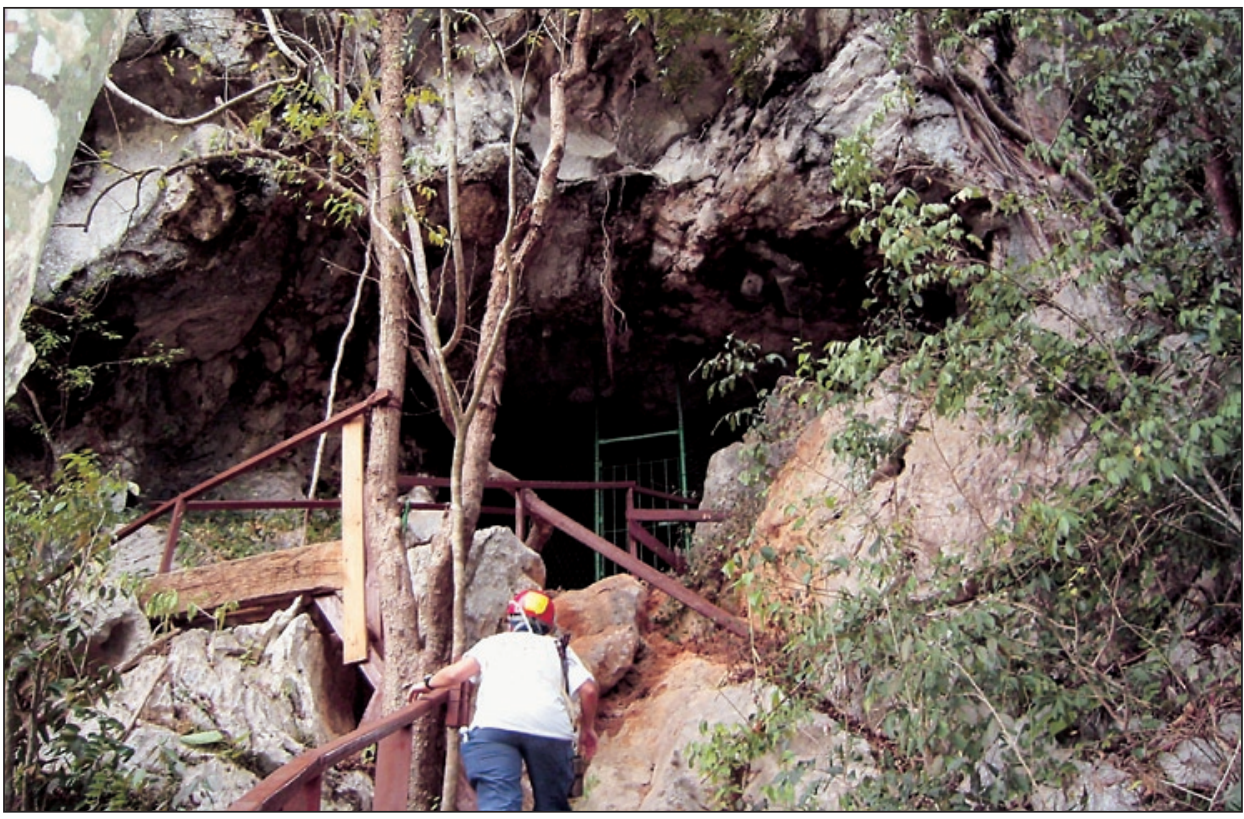

Fig. 8: Entrance of Cueva de las Avispas, showing part of the wooden ladder serving the tourist passage. 


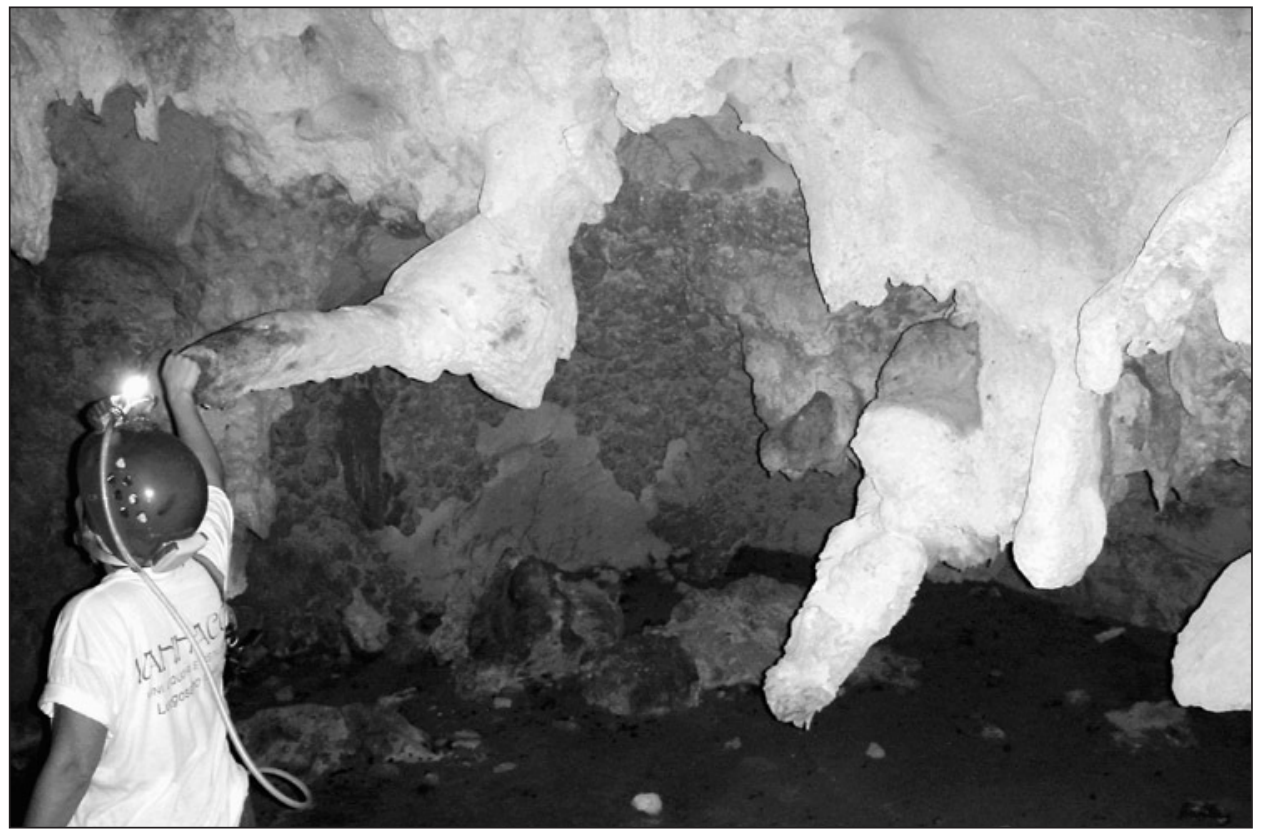

Fig. 9: Stalactites dipping outward in the Cueva de las Avispas.

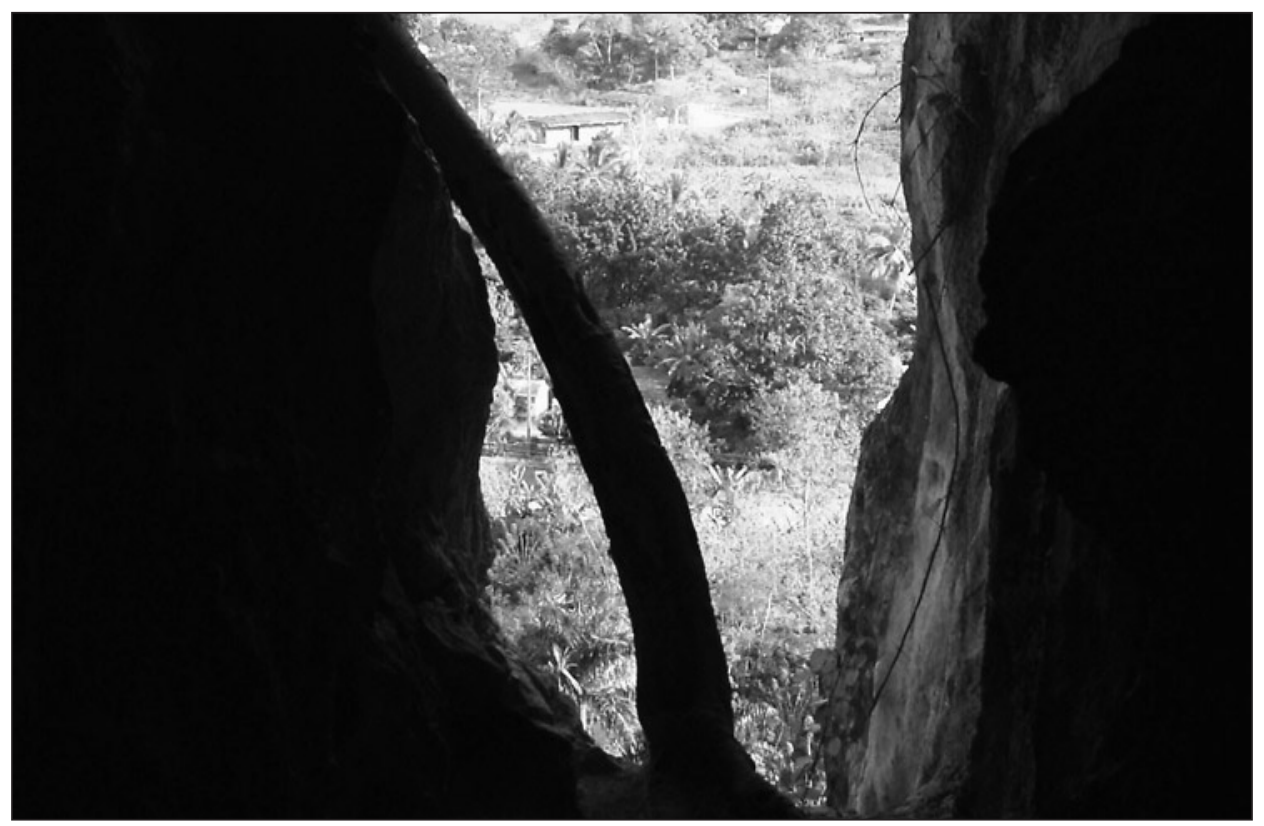

Fig. 10: Natural windows from the Cueva de las Avispas toward the Valle de Santo Tomás below. 
between the lowest and highest points of $70 \mathrm{~m}$ (Carrasco et al. 2002). The tourist area is the part nearest the entrance, and is restricted to a one-third of the cave, whilst the remaining two-thirds of the cavity are only visited by occasional groups of researchers, speleologists and speleotourists.

Cave monitoring is poorly developed in the Caribbean, and is hampered by a general lack of awareness of its importance and utility. Other impediments include limited funding, the absence of requisite equipment, and the scarcity of qualified personnel (Day \& Koenig 2002). Monitoring, that

\begin{tabular}{|c|c|c|}
\hline no. & & karst region \\
\hline 1 & \multirow{9}{*}{ West karst regions } & Guanahacabibes Plain \\
\hline 2 & & Sierra de los Organos \\
\hline 3 & & Sierra del Rosario \\
\hline 4 & & Plain of Pinar del Rio \\
\hline 5 & & Ridges and plains north of La Habana \\
\hline 6 & & Plain south of La Habana and Matanzas \\
\hline 7 & & Zapata Plain \\
\hline 8 & & Plains and ridges of the northern sector of Isla de la Juventud \\
\hline 9 & & Plain of the southern sector of Isla de la Juventud \\
\hline 10 & \multirow{14}{*}{ Central karst regions } & Manacas Plain \\
\hline 11 & & Northern Cordillera of Villa Clara \\
\hline 12 & & Guamuhaya Ridges \\
\hline 13 & & Island Group of Sabana-Camaguey \\
\hline 14 & & Ridges of Punta Alegre-Turiguanò \\
\hline 15 & & Ciego de Avila Plain \\
\hline 16 & & Plain of northern Camaguey \\
\hline 17 & & Cubitas Ridges \\
\hline 18 & & Plain of southern Camaguey \\
\hline 19 & & Maniabòn \\
\hline 20 & & Nipe Plain \\
\hline 21 & & Najasa Ridges \\
\hline 22 & & Cauto Plain \\
\hline 23 & & Island Group of los Jardines de la Reina \\
\hline 24 & \multirow{8}{*}{ East karst regions } & Mayarì Ridges \\
\hline 25 & & Moa Ridges \\
\hline 26 & & Mesetas de Guaso, Canasta and Yateras \\
\hline 27 & & Plain and Meseta of Maisì \\
\hline 28 & & Meseta of Imìas \\
\hline 29 & & Plain and Meseta of Cabo Cruz \\
\hline 30 & & Baire Ridges \\
\hline 31 & & Plain of Santiago de Cuba \\
\hline
\end{tabular}

Table 1: List of karst regions of Cuba (after Nuñez Jimenez, 1984). Numbers refer to figure 1. 
is any continuous observation aimed to establish the state of a cave, and eventual changes in its environment, is an extremely important activity for protection and safeguarding of karst caves, in particular show caves (Kranjc 2002; Armstrong \& Osborne 2002). As Day and Koenig (2002) observe, due to these reasons, monitoring might best be instituted in some of the better known, more heavily visited caves whose scientific and other significance are already recognized and whose conservation thus perhaps engenders the most ready support. This could be exactly the case at Santo Tomàs, where simple and low-cost monitoring, for example, might be started as regards water quality and the control of the most significant micro-climatic and environmental parameters. It has to be considered, on the other hand, the high complexity of karst caves, that derives from seasonal and other temporal variations, and by a pattern of spatial variations, including, but not limited to, microclimatic and bioenvironmental variations. Due to these reasons, each specific karst area or cave has its own distinctive set of environmental elements and visitor patterns, and requires a different management context as well (Hamilton-Smith 2002). As a consequence, monitoring programs and framework have to differ from site to site, based upon detailed study of the local characteristics of the cave.

\section{DISCUSSION}

Tourism in Cuba is essentially related to natural landscapes along the coasts, beaches and coral reefs, integrated by social and cultural traditions. Main areas of provenance of tourists are the United States of America (51\% of total arrivals) and western Europe (about 18\%). In the last 15 years, however, tourist movement from the United States decreased some 10\%, whilst the 5\% increase from Europe testifies the trend toward long-distance travels (Salinas 1999; OMT 1999).

Concentration of the main tourist areas along the coasts, in view of the expected increase in the overall number of visitors (40 millions in 2020 at Cuba, based upon estimates from the Organizacion Mundial del Turismo) highlights the need to re-qualification of the demand, and to move a percentage of tourists inland, toward more convenient areas (Mangano and Mundet I Cordan 2002).

To diminish the strong difference existing between coastal areas where tourism concentrates and inland, and to develop a ecological sustainable tourism, in an ethical perspective for local inhabitants, are among the main aims of the Declaracion de Santo Domingo, which has been approved by the governments of the Associación de Estados del Caribe in April 1999, when the Zona de Turismo Sustentable del Caribe and the related Plan de Acción were created.

At Cuba, since 1996 tourism has become the most important economical activity, surpassing, after centuries, the production of sugar canes. A slow tendence toward ecotourism started in the last years, with presence of hotels even inland.

Cuba has several naturalistic phenomena of interest: from the afore mentioned coasts and beauty of the sea, to the over 7,000 species of plants that pose it among the most important richest biological areas in the world, to the variety of karst landforms and caves.

The very fragile natural balance in karst areas may be negatively affected, or even destroyed forever, by the human intervention. However, we know very well that it is not possible to exclude entirely the man from karst and to preserve all the karst regions from any human activity (Panoš, 1980). Thus, rational ways to live with karst landscapes and resources have to be looked for.

In the possible uses of karst, ecotourism and recreational activities are considered among the least producing negative impacts on the environment, if correctly carried out with respect for the 
karst, including the local inhabitants of karst areas as well.

Human impacts upon the karstlands of the Caribbean, and of Central America as well, have been long term and severe except in the most isolated and rugged areas and where population densities are lowest (Day 1993; Kueny \& Day 1998). This was, luckily, the case at Santo Tomàs, which is located in a rural area quite far from the main routes followed by most of the tourist activity. Such a location favoured so far the preservation of the karst environment, that has to be considered today together with the high potentiality offered by the Santo Tomàs karst system, including those of archaeological and historical importance. It is well-known, in fact, that many karst caves worldwide were inhabited by man during the Palaeolithic and the Neolithic, and have thus become extremely important since they contain valuable human remnants, products of the ancient industry, outstanding protographic and sculptural works. All of these are, as observed by Panoš (1980), uncoverable documents to study the prehistoric stages of the human civilization.

At Santo Tomàs, the presence of a beautiful natural setting, both at the surface and in the cave, the high value of the local wildlife and vegetation, and the many archaeological findings, are well suitable elements to indicate this karst system as one of the best location for an ecological sustainable tourism, at the same time offering a very appropriate site for performing international karst and speleological research.

\section{ACKNOWLEDGEMENTS}

This paper is part of the work carried out during the italian-cuban expedition "Santo Tomàs 2003". The Authors express their warmest thanks to all the participants to the expedition, and to the personnel of the Escuela Nacional de Espeleologia "Antonio Nuñez Jimenez" for their kind hospitality. A particular thank to Rosa Potenza (Gruppo Puglia Grotte), which effort was crucial for the organization of the expedition, and its success.

\section{REFERENCES}

Armstrong, R. \& L. Osborne, 2002: Significance and monitoring. - Acta Carsologica, 31 (1), 21-33, Ljubljana.

Carrasco F., I. Vadillo, C. Liñán, B. Andreo \& J.J. Durán, 2002: Control of environmental parameters for management and conservation of Nerja Cave (Malaga, Spain). - Acta Carsologica, 31 (1), 105-122, Ljubljana.

Cigna A.A., 2001: Evaluation of the tourist impact in the Kartchner Caverns (Arizona, USA). - Proc. $13^{\text {th }}$ International Congress of Speleology, vol. 2, 188-192.

Day M.J., 1978: Morphology and distribution of residual limestone hills (mogotes) in the karst of northern Puerto Rico. - Geol. Soc. Am. Bull., 89, 426-432, Boulder.

Day M.J., 1993: Human impacts on Caribbean and Central America karst. - In: Williams P.W. (ed.), Karst terrains: Environmental Changes and Human Impact. Catena, suppl. 25, 109-125.

Day M. \& S. Koenig, 2002: Cave monitoring priorities in Central America and the Caribbean. - Acta Carsologica, 31 (1), 123-134, Ljubljana.

Gardner T.W., 1987: Overview of Caribbean geomorphology. - In: Graf W.L. (ed.), Geomorphic Systems of North America, Geol. Soc. Am., Boulder. 
Hamilton-Smith E.A.M., 2002: Management assessment in karst areas. - Acta Carsologica, 31 (1), 13-20, Ljubljana.

Kranjc A., 2002: Introduction. Monitoring of karst caves. - Acta Carsologica, 31 (1), 9-10, Ljubljana.

Kueny J.A. \& M.J. Day, 1998: An assessment of protected karst landscapes in the Caribbean. - Caribbean Geography, 9 (2), 87-100.

Mangano S. \& L. Mundet i Cordan, 2002: I Caraibi: un nuovo Mediterraneo? Il caso di Cuba. - Boll. Soc. Geogr. It., ser. XII, 7, 89-104.

Mann S.L., R.J. Steidl \& V.M. Dalton, 2002; Effects of cave tours on breeding Myotis Velifer. Journal of Wildlife Management, 66 (3), 618-624.

Monroe W.H., 1968: The karst features of northern Puerto Rico. - Bull. Nat. Spel. Soc., 30, 75-86.

Nuñez Jimenez A., 1984 : Cuevas y carsos. - Editorial Cientifico-Tecnica, Ciudad de La Habana.

Nuñez Jimenez A., 1990: La Gran Caverna de Santo Tomàs. - Sociedad Espeleologica de Cuba, Ed. Plaza Vieja, Cuba.

Organizacion Mundial del Turismo (OMT), 1999: Anuario de estadisticas de turismo. - Organizacion Mundial del Turismo, Madrid, 1999.

Panoš V., 1980: Potentialities and problems of utilization of the karst. - Proc. Int. Symp. "Utilization of Karst Areas", Trieste (Italy), 28-30 march 1980, 55-60.

Parise M. (ed.), 2004: Nel Caos della Gran Caverna di Santo Tomàs. Speleologia, 50, 58-67.

Salinas E., 1999: Marketing y comercialización del ecoturismo en el Caribe. - Estudios y Perspectivas en Turismo, 2, 120-134.

Schenck J., C. Porter \& D. Coons, 1999: NSS expedition to Cuba. - Nat. Spel. Soc. News, 300302.

Shaw T., 2003: Caribbean Islands: history. - In: Gunn J. (ed.), Encyclopedia of caves and karst science, Routledge, 191-192.

Tarhule-Lips R., 2003: Caribbean Islands. - In: Gunn J. (ed.), Encyclopedia of caves and karst science, Routledge, 189-190.

Travous K.E. \& J.P. Ream, 2001: Developing and managing an environmentally responsible tourist cave. - Proc. $13^{\text {th }}$ International Congress of Speleology, vol. 2, 231-233.

Tyc A., 2003: Cuba. - In: Gunn J. (ed.), Encyclopedia of caves and karst science, Routledge, 271272.

Valdes Suarez M., 2005: Gran Caverna de Santo Tomàs (Cuba): storia di una esplorazione in corso di svolgimento. - Grotte e dintorni, 8, Castellana-Grotte. 